\title{
Reconstruction of Vulva and Perineal Defects After Gynecological Oncological Surgery and Effectiveness of Local Flaps
}

\author{
Jinekolojik Onkolojik Cerrahi Sonrası Oluşan Vulva ve Perine Defektlerinin Rekonstrüksiyonu ve \\ Lokal Fleplerin Etkinliği
}

\author{
Tolga AKSAN ${ }^{1}$ \\ (1) 0000-0002-3328-2652 \\ Ateş KARATEKE ${ }^{2}$ \\ (D) 0000-0002-0199-6474 \\ Orkun UZUNEYÜPOĞLU ${ }^{1}$ \\ (D) 0000-0002-7136-3955 \\ Muhammed Beşir ÖZTÜRK ${ }^{1}$ \\ (1) 0000-0002-8977-3741 \\ Mehmet KÜÇÜKBAŞ² \\ (1) 0000-0001-6697-8990
}

\begin{abstract}
${ }^{1}$ Department of Plastic and Reconstructive Surgery, Istanbul Medeniyet University Faculty of Medicine, Istanbul, Turkey

${ }^{2}$ Department of Gynecology and Obstetrics, Istanbul Medeniyet University Faculty of Medicine, Istanbul, Turkey
\end{abstract}

\section{Corresponding Author Sorumlu Yazar \\ Tolga AKSAN \\ tolga_aksan@hotmail.com}

Received / Gelis Tarihi : 07.04.2021 Accepted / Kabul Tarihi : 09.07.2021 Available Online /

Çevrimiçi Yayın Tarihi : 16.07.2021

\begin{abstract}
Aim: Although most defects can close by primary suturing after radical surgery of gynecological malignancies, different reconstruction options are available when large defects that require reconstruction occur. In this study, we present the treatment strategy and results for patients who underwent reconstruction after resection for gynecological cancer in the vulva and perineum.

Material and Methods: A total of 18 patients who underwent reconstruction between May 2018 and July 2020 were included in this retrospective study. Demographics and clinical data, the resection operation, characteristics of the defect, and the reconstruction methods applied were evaluated. Postoperative treatment strategy and complication rates were evaluated. Results: The mean age was $62.3 \pm 13.2(42-83)$ years. $88.9 \%$ of the patients had additional diseases. Pelvic exentration was performed in $5(27.8 \%)$ patients, anterior resection in $2(11.1 \%)$ patients and vulvectomy in $11(61.1 \%)$ patients. The most common malignancy was squamous cell carcinoma, and mean defect size was $106 \pm 97(12-476) \mathrm{cm}^{2}$. Reconstruction was performed with a local fasciocutaneous flap in $16(88.9 \%)$ patients, pedicled rectus myocutaneous flap in one (5.6\%) patient, and skin graft in one (5.6\%) patient. Wound complications occurred in $5(27.8 \%)$ patients, partial flap necrosis in one (5.6\%) patient, and recurrence in one (5.6\%) patient in the long term. Conclusion: It is possible to reconstruction most of the vulva and perineal defects with local flaps after oncological resections, Considering the characteristics of the area and patient comorbidities, it should be kept in mind that prolonged wound problems may be seen, especially in vulvectomy patients.
\end{abstract}

Keywords: Vulvectomy; pelvic exenteration; reconstructive; neoplasm; morbidity; wounds.

\section{ÖZ}

Amaç: Jinekolojik malignitelerin radikal cerrahisi sonrası çoğu defekt primer sütüre edilerek kapatılabilse de rekonstrüksiyon gerektiren geniş defektler oluştuğunda farklı rekonstrüksiyon seçenekleri de mevcuttur. Bu çalışmada, vulva ve perine bölgesinde jinekolojik kanser nedeniyle rezeksiyon sonrası rekonstrüksiyon uygulanan hastalarda uyguladığımız tedavi strateji ve sonuçları sunulmaktadır.

Gereç ve Yöntemler: Bu geriye dönük çalışmaya Mayıs 2017 ve Temmuz 2020 arasında rekonstrüksiyon uygulanan toplam 18 hasta dahil edildi. Hastaların demografik ve klinik bilgileri rezeksiyon operasyonu, defekt özellikleri, uygulanan rekonstrüksiyon yöntemleri değerlendirildi. Operasyon sonrası tedavi stratejisi ve komplikasyon oranları değerlendirildi. Bulgular: Hastaların ortalama yaşı 62,3 $\pm 13,2$ (42-83) yıl olarak saptandı. Hastaların \%88,9'unda ek hastalık bulunmaktaydı. Beş $(\% 27,8)$ hastada pelvik egzantasyon, $2(\% 11,1)$ hastada anterior rezeksiyon ve $11(\% 61,1)$ hastada vulvektomi uygulanmıştı. En sık görülen malignite skuamöz hücreli karsinom ve ortalama defekt genişliği $106 \pm 97(12-476) \mathrm{cm}^{2}$ olarak saptand. On altı $(\% 88,9)$ hastada lokal fasyokutan flep, bir $(\% 5,6)$ hastada pediküllü rektus myokutan flebi ve bir $(\% 5,6)$ hastada deri grefti ile onarım yapıldı. Beş $(\% 27,8)$ hastada yara yeri komplikasyonları, bir $(\% 5,6)$ hastada parsiyel flep nekrozu ve uzun vadede bir $(\% 5,6)$ hastada nüks gelişti.

Sonuç: Jinekolojik onkolojik rezeksiyonlar sonrası vulva ve perine defektlerinin birçoğunun lokal flepler ile başarılı bir şekilde kapatılması mümkündür. Özellikle vulvektomi hastalarında bölgenin özellikleri ve hasta komorbiditeleri dikkate alındığında uzamış yara yeri problemleri görülebileceği akılda bulundurulmalıdır.

Anahtar kelimeler: Vulvektomi; pelvik egzantrasyon; rekonstrüktif; neoplazm; morbidite; yara. 


\section{INTRODUCTION}

Vulva and perineum defects most commonly occur due to curative surgical resections. Less commonly, it can also be caused by trauma and necrotic soft tissue infections (1). The most common histological type in vulvar cancers is squamous cell carcinoma associated with the human papilloma virus (HPV). Although older patients are the predominant population in cancer patients, there has been an increase in the diagnosis of HPV-associated in-situ carcinomas and different histological types in younger women. Other histological tumor types affecting the vulvar region are extra-mammary Paget's disease, melanoma, sarcoma, basal cell carcinoma, adenocarcinoma, and verrucous carcinoma (2). Ablative surgery of vulvar cancers often causes extensive soft tissue defects, and rapid postoperative recovery is required to allow adjuvant therapies (3-7).

For an aesthetically and functionally successful reconstruction, adequate skin cover and well-vascularized tissue should be transferred to the defect area in such a way that no dead space is left, sufficient vaginal and urethral opening with minimal urine and stool contamination (5-9). In the literature, some algorithms for the reconstruction of these defects have been published in the past, but in practice, the management of these defects depends not only on the size and location of the defect, but also on the patient's comorbidities, adjuvant treatments (radiotherapy and chemotherapy), the stage of the disease, and the experience of the reconstructive surgeon (5-7). This study, it was aimed to present the conclusions we have obtained by examining the reconstruction methods applied based on the key points mentioned above in vulvar and perineal defects that occur after gynecological cancer surgery in our clinic.

\section{MATERIALS AND METHODS}

In the study, which was approved by the clinical research ethics committee (Istanbul Medeniyet University, 2020/0643) and planned retrospectively, the resections which is applied to the perineum of the vulva due to pelvicvulvar gynecological malignancy by Istanbul Medeniyet University Göztepe Prof. Dr. Süleyman Yalçın City Hospital Gynecology and Obstetrics Clinic between May 2018 and July 2020 were addressed. The reconstructions performed by Plastic, Reconstructive and Aesthetic Surgery Clinic of the patients whose primary repair of the defect after resection was not possible were scanned. Patients' demographic information, clinical characteristics, comorbidities (diabetes, hypertension, smoking, etc.), previous surgeries in this region, resection surgery, defect characteristics, reconstruction methods, duration of mobilization, post-operative treatment protocol, and length of stay in hospital were evaluated. Histopathological diagnosis, recurrence rates, complications were scanned and the results were evaluated.

All patients were operated under general anesthesia and in the lithotomy position. Resection of the tumor in all patients was performed by the same gynecologist and all reconstructions were performed by the same plastic surgeon. Considering the characteristics of the defect that occurred after resection and the patient, reconstruction was performed with a local flap, distant flap, or skin graft (Figure 1. A, B).

In cases where total pelvic exenteration and anterior resection were performed, a part of the transferred flap, up to one-third of it as needed, was de-epithelized and tightly sutured to each other, and it was used to support the cavity formed in the pelvic floor due to resection and support the floor by filling the space formed in the pelvic floor due to resection (Figure 2. A-E).

After subcutaneous was closed with absorbable sutures in such a way that skin tension is minimal, vulva perineum area and mucosal junction surfaces were closed with absorbable (polyglactin) sutures. Flap donor areas in the thigh area were closed with non-absorbable (polypropylene) sutures.

One or two hemovac drains were used in all patients who underwent with flap surgery. In addition, permanent colostomy was performed by the general surgery specialist and permanent urostomy by the urology specialist in all patients who underwent exenteration. In patients who underwent anterior resection, only urostomy was performed.

In the postoperative period, immobilization was applied for 1-3 days. During the immobilization period, prophylactic anticoagulant (Fraksiparin 6000 U/day-subcutaneous) treatment was given. The first dose

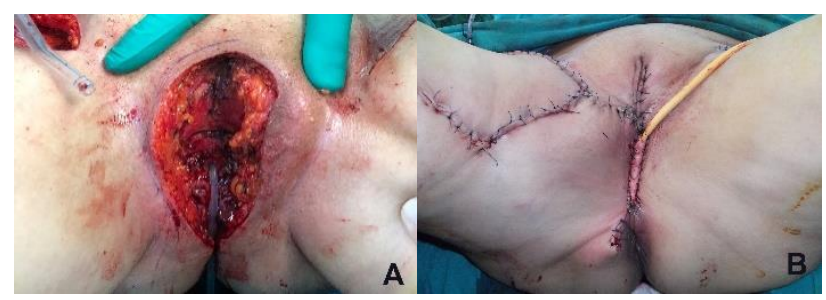

Figure 1. The patient underwent radical vulvectomy due to squamous cell carcinoma. The posterior-based fastocutaneous rotation flaps were elevated from the inner side of the right thigh to close the more defect (A) on the right side, and the defect was closed by detaching the existing skin on the left $(\mathbf{B})$.

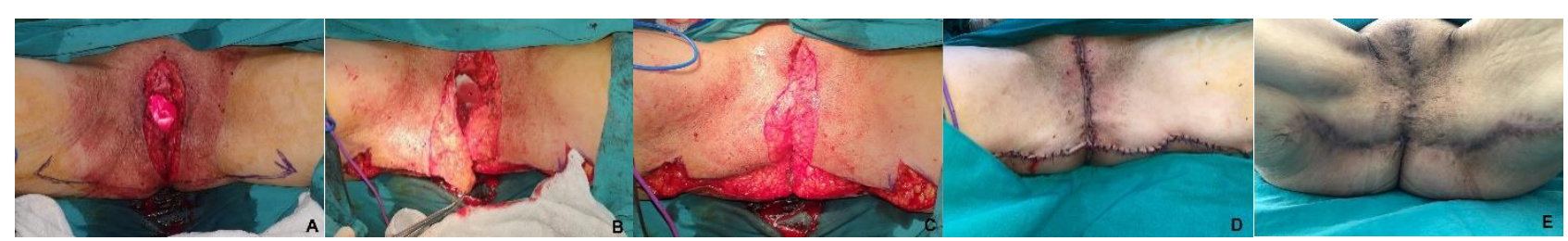

Figure 2. To close the defect of the patient who underwent pelvic exenteration due to squamous cell carcinoma (A), the anteriorbased fastocutaneous rotation flaps were elevated from the inner thigh to close the defect, the ends were de-epithelized (B), the ends were used to fill the space in the pelvis $(\mathbf{C})$, and the skin defect was closed (D). Postoperative 5 months view of the patient (E). 
of cefazolin $1000 \mathrm{mg}$ (intravenous) was administered peroperatively and 3 doses were administered per day for 5-7 days. Foley catheter was used for at least 5 days in all patients who did not undergo urostomy, in the postoperative period. In patients who did not undergo colostomy, a liquid diet (regimen-1) was given for 3 days and $250 \mathrm{mg}$ of Lyophilized Saccharomyces boulardii was administered orally 3 times a day to reduce the frequency of defecation. The dressing was changed every day during the hospitalization period. In patients who underwent vulvectomy, daily vaginal tampons were used for 3 days to prevent wetting of the suture area with secretions. When the 24-hour amount of material coming from the drains fell below 25 milliliters, the drains were withdrawn. Patients were advised not to sit in a sitting position for more than a few minutes for two weeks. Non-absorbable sutures were removed after 14-21 days. Absorbable sutures were left until they dissolve spontaneously.

In the long term, recurrence rates and functional results were evaluated, and all results were visually examined. Six months after the reconstruction, all patients were asked about their satisfaction with the reconstruction.

\section{Statistical Analysis}

Statistical analysis of the data was performed by using the SPSS v.22 (IBM SPSS Statistics v.22.0) package program. Descriptive statistics were calculated as mean and standard deviation for numerical variables, and as number and percentage for categorical variables. The Student's t-test was used to compare two independent groups. A p value of less than 0.05 was considered significant.

\section{RESULTS}

In the study in which a total of 18 patients were included, the results are summarized in Table 1 . The mean age of the patients was $62.3 \pm 13.2$ (42-83) years. Average body mass index was observed as $29.3 \pm 4.5(24.1-39.0) \mathrm{kg} / \mathrm{m}^{2}$. Although $16(88.9 \%)$ of the patients had comorbid diseases, $10(55.6 \%)$ patients had more than one comorbidity. The most common accompanying disease was hypertension. Three $(16.7 \%)$ patients previously had a history of malignancy in a different region. One $(5.6 \%)$ patient was previously operated for vulvar malignancy in an external center and subsequently relapsed. Seven (38.9\%) of the patients received neoadjuvant chemotherapy and radiotherapy, and one $(5.6 \%)$ patient received only neoadjuvant chemotherapy.

Total pelvic exentration was performed in 5 (27.8\%) patients, anterior resection in $2(11.1 \%)$ patients, radical vulvectomy in $7(38.9 \%)$ patients, partial vulvectomy in $3(16.7 \%)$ patients and superficial vulvectomy in one $(5.6 \%)$ patient. The smallest defect was $4 \times 3 \mathrm{~cm}\left(12 \mathrm{~cm}^{2}\right)$ and the largest was $30 \times 14 \mathrm{~cm}\left(420 \mathrm{~cm}^{2}\right)$.

For the reconstruction of the defects, fasciocutaneous rotation, transposition or $\mathrm{V}-\mathrm{Y}$ advancement flaps prepared from the bilateral medial thigh in $13(72.2 \%)$ patients, unilateral medial thigh in $3(16.7 \%)$ patients and vertical skin island rectus abdominis myocutaneous flap in one $(5.6 \%)$ patient, and partial thickness skin graft in one $(5.6 \%)$ patient were applied. Bilateral superficial inguinal lymph node dissection was performed in $7(38.9 \%)$ of the patients. The mean length of hospital stay was $21.1 \pm 5.4$ (8-120) days, and the mean follow-up period was $12.3 \pm 7.3$ (2-30) months.
As complications, wound infection and partial suture separation were observed in $5(27.8 \%)$ patients. All patients with this condition were those who underwent vulvectomy and were repaired with flap. Three of them were re-operated and revised. Secondary healing was seen in other patients with wound care. In one patient who underwent vulvectomy, due to partial flap necrosis, repeated debridements and restorations were performed; however, wound healing was achieved after 4 months. While the mean body mass index of patients with wound complications was $34.8 \pm 3.5(32.2-39.0) \mathrm{kg} / \mathrm{m}^{2}$, it was observed as $26.5 \pm 1.7(24.1-30.1) \mathrm{kg} / \mathrm{m}^{2}$ in patients without complications. This difference was found to be statistically significant $(\mathrm{p}=0.001)$. Enterococcus faecalis were grown in 4 and fungal growth in 1 of the culture samples taken from the wound of patients with wound infection. According to the culture results, sensitive antibiotics were administered for 7-10 days. In one patient who underwent vulvectomy and bilateral fasciocutaneous flap was applied, local recurrence developed in the $10^{\text {th }}$ month postoperatively and wide resection was performed again; the defect was reconstructed with a unilateral fasciocutaneous local flap. There was no significant difference in the complication rates of patients who received chemotherapy and/or radiotherapy and those who underwent lymph node dissection $(\mathrm{p}=0.650)$.

Table 1. Patient characteristics and treatment summary

\begin{tabular}{|c|c|}
\hline Age (years) & $62.3 \pm 13.2(42-83)$ \\
\hline Body mass index $\left(\mathrm{kg} / \mathrm{m}^{2}\right)$ & $29.3 \pm 4.5(24.1-39.0)$ \\
\hline \multicolumn{2}{|l|}{ Comorbidity (total 25 for 16 patients) } \\
\hline Hypertension & $8(44.4 \%)$ \\
\hline Hypothyroidism & $4(22.2 \%)$ \\
\hline Diabetes & $2(11.1 \%)$ \\
\hline Coronary artery disease & $3(16.7 \%)$ \\
\hline Arrhythmias & $2(11.1 \%)$ \\
\hline Smoking & $3(16.7 \%)$ \\
\hline Other & $3(16.7 \%)$ \\
\hline \multicolumn{2}{|l|}{ Preoperative neo-adjuvant therapy } \\
\hline Radiotherapy & $7(38.9 \%)$ \\
\hline Chemotherapy & $6(33.3 \%)$ \\
\hline \multicolumn{2}{|l|}{ Previous cancer history (another system) } \\
\hline Breast cancer & $1(5.6 \%)$ \\
\hline Hodgkin lymphoma & $2(11.1 \%)$ \\
\hline \multicolumn{2}{|l|}{ Resection operation performed } \\
\hline Vulvectomy & $11(61.1 \%)$ \\
\hline Anterior Resection & $2(11.1 \%)$ \\
\hline Pelvic exentration & $5(27.8 \%)$ \\
\hline Defect size $\left(\mathrm{cm}^{2}\right)$ & $106 \pm 97(12-476)$ \\
\hline Inguinal lymph node dissection (bilateral) & $7(38.9 \%)$ \\
\hline \multicolumn{2}{|l|}{ Reconstruction operation performed } \\
\hline Bilateral fasciocutaneous flap & $13(72.2 \%)$ \\
\hline Unilateral fasciocutaneous flap & $3(16.7 \%)$ \\
\hline Rectus abdominis myocutaneous flap & $1(5.6 \%)$ \\
\hline Skin grafting & $1(5.6 \%)$ \\
\hline \multicolumn{2}{|l|}{ Complications } \\
\hline Wound infection-detachment & $5(27.8 \%)$ \\
\hline Partial flap necrosis & $1(5.6 \%)$ \\
\hline Relapse & $1(5.6 \%)$ \\
\hline \multicolumn{2}{|l|}{ Pathology } \\
\hline Squamous cell carcinoma & $11(61.1 \%)$ \\
\hline High-grade squamous intraepithelial lesion & $4(22.2 \%)$ \\
\hline Paget's disease & $2(11.1 \%)$ \\
\hline Malignant melanoma & $1(5.6 \%)$ \\
\hline
\end{tabular}


In the long term, complete wound closure was achieved within one month at the latest, except for prolonged wound closure (4 months) in one patient. No patient developed chronic urinary tract infection. Vaginal osteal stenosis did not develop in any patient. In three patients, the increased vaginal discharge regressed within 3 months and became normal. Sensory return was observed at the flap area for one year in all patients. Among the patients who underwent vulvectomy, 4 patients (under 55 years of age) who had an active sexual life stated that they returned to their sexual activities. Other patients stated that they were not sexually active. Total patient satisfaction was determined as $88.9 \%$.

Histopathological examinations revealed that the most common malignancy was squamous cell carcinoma in $11(61.1 \%)$ patients. High-grade squamous intraepithelial lesion (HGSIL) in $4(22.2 \%)$ patients, vulvar Paget's disease in $2(11.1 \%)$ patients, and malignant melanoma in $1(5.7 \%)$ patient were observed.

Looking at the long-term complications, prolonged wound closure (4 months) was observed in one patient. In other patients, complete wound closure was achieved within one month at the latest. No patient developed chronic urinary tract infection. Vaginal osteal stenosis did not develop in any patient. Increased vaginal secretion was detected in three patients; it regressed within 3 months and reached the normal level.

\section{DISCUSSION}

Since the vulvar region has a flexible skin, many defects can be primarily closed after large resections $(1,10)$. The number of cases requiring reconstruction in vulvar oncological resections constitutes approximately $3 \%$ of all cases (10). However, the selection of the reconstruction technique of the defect that occurs after primary nonrepairable vulvar and perineal resections may vary according to the defect and many factors related to the patient. Local fasciocutaneous flaps are usually the first choice of many surgeons in the absence of extensive tissue deficiency (2,7). Successful results have even been reported by leaving primary non-closable defects to secondary healing (11). The blood circulation of the perineal area, gluteal region and medial part of the thigh is provided by a rich perforator vascular system. Due to the pudental arteries, branches of the deep femoral artery and branches of the inferor gluteal arteries, the blood supply of this area is quite well $(12,13)$. Based on this blood flow pattern, many options have been described in perineal region defects including rotation, advancement and perforator flaps. Bilateral flaps can be performed in cases where unilateral flap is insufficient or to provide symmetry. Oily and loose donor areas allow primary closure $(2,14)$. Considering these advantages of local flaps in our cases, we preferred the use of local flaps primarily and often.

Defects that occur after resection of malignancies resulting from irregular and uncontrolled growth in external genital structures such as vulvar cancers are also irregular. Not specific subunits; It can also affect the structures in the vulva neighborhood (7). Therefore, we think that most defects should be planned within an algorithm and not be limited to a few reconstruction options. Considering the basic principles of plastic surgery and the characteristics of adjacent tissues, we anticipate that most defects can be repaired with local flaps. In all vulvectomy patients included in the study; all defects except one patient could be closed with local flaps, and in a large case $(30 \times 14 \mathrm{~cm})$ that could not be closed with local flaps, they were repaired with a partial thickness skin graft. Repair with local flaps also provides shorter operation time and better tissue compatibility $(4,7,15)$.

In defects that occur after pelvic excentration or anterior resection, a defect that connects the abdominal cavity and the external environment must be safely closed and the dead space formed in place of the resected organs must be filled (7). In such cases, although most references suggest distant and voluminous flaps such as the epigastric region, rectus abdominis, or vastus lateralis, we used anteriorbased large fasciocutaneous rotation flaps elevated from the bilateral inner thigh in 6 of these patients (7). We used the medial parts of the flaps by disepithelializing according to the need and to the extent that tension allowed, in order to close the dead space in the pelvic floor. However, since one patient had a large skin defect $(20 \times 12 \mathrm{~cm})$ with a pelvic dead space, we performed the defect repair using the vertical skin island rectus abdominis myocutaneous flap, through which the pedicle passes through the abdominal area.

Malignancies are more common in older ages and accompanying diseases are also more common in older ages (16). Therefore, patients with gynecological malignancies often have accompanying diseases. This situation also increases the frequency of complications during and after surgery. $88.9 \%$ of our patients also had comorbid diseases. Although anesthesia-related complications were not observed in our patient group, wound-related complications were observed in $33.3 \%$ of all patients. Also, resections that require reconstruction are more prone to complications than primary repairable defects. Martin et al. (10) in his study; complication rates were examined in 2098 patients who were operated and reconstructed for vulvar cancer, and they found that all major and minor complication rates were $45 \%$. In the same study, the rate of patients who do not require reconstruction was stated as $10 \%$.

Obesity in the reconstruction of vulva and perineum defects; emerges as another disadvantage. Increased body mass index and obesity are important negative factors in the development of wound complications $(11,17)$. In our study, body mass index was $34.8 \pm 3.5(32.2-39.0) \mathrm{kg} / \mathrm{m}^{2}$ in patients with wound complications; determination of body mass index as $26.5 \pm 1.7(24.1-30.1) \mathrm{kg} / \mathrm{m}^{2}$ in patients without wound complications supports these findings.

As is known, having received chemotherapy and/or radiotherapy before the operation slows down wound healing $(11,18)$. However, in our patients, as expected, there was no significant difference between the patients who developed and did not develop complications, between the rates of radiotherapy and/or chemotherapy. Similarly, although it was reported that lymph node dissection increased wound-related complications, in our study, there was no significant difference in the complication rate between patients who underwent and did not undergo lymph node dissection (18).

In our opinion, the exposure of the moist labium minor or vaginal mucosa after resections involving labium majus 
and the suturing of this area with the skin tissue is another factor that makes wound healing difficult. Vaginal secretions slow down wound healing and increase the rate of infection by causing maceration in the suture line $(2,19)$. Therefore, even if we use a vaginal tampon for 3 days after surgery, it is not possible to eliminate this effect. For this reason, we think that there is inevitably prolonged wound healing in patients undergoing vulvectomy.

The limitations of our study may be that the number of patients was limited to 18 and that many different reconstruction options that were defined and reported as successful were not implemented. However, obtaining a large and single-center series will take a very difficult and long process due to the proportional low number of cases requiring reconstruction in oncological resections in the vulva region (10). We think that our local flap strategy, which we primarily apply in such cases we encounter, provides successful and high patient satisfaction.

\section{CONCLUSIONS}

After radical resection of gynecological malignancies, large defects may occur in the vulva and perineum. Reconstruction of these defects with minimal complications should be aimed; reconstruction should be planned according to the characteristics of each patient and defect. Defects in this area, local tissues are often sufficient to close the defects. Keeping the recovery period short by providing minimal morbidity should be considered, especially in advanced stage patients, as adjuvant treatments may be required. It should be kept in mind that the wound healing process may be prolonged, especially in vulvectomy cases with a high body mass index, where the vaginal mucosa and skin are sutured together, because the region is prone to maceration and infection, and the suturing of tissues with different histological features to each other.

Ethics Committee Approval: The study was approved by the Clinical Research Ethics Committee of Istanbul Medeniyet University (18.11.2020, 643).

Conflict of Interest: None declared by the authors.

Financial Disclosure: None declared by the authors.

Acknowledgements: None declared by the authors.

Author Contributions: Idea/Concept: TA, AK; Design: TA; Data Collection/Processing: TA, OU; Analysis/Interpretation: TA, OU; Literature Review: TA, OU; Drafting/Writing: TA, OU; Critical Review: MBÖ, MK.

\section{REFERENCES}

1. Salgado CJ, Chim H, Skowronski PP, Oeltjen J, Rodriguez M, Mardini S. Reconstruction of acquired defects of the vagina and perineum. Semin Plast Surg. 2011;25(2):155-62.

2. Fin A, Rampino Cordaro E, Guarneri GF, Revesz S, Vanin M, Parodi PC. Experience with gluteal V-Y fasciocutaneous advancement flaps in vulvar reconstruction after oncological resection and a modification to the marking: Playing with tension lines. Int Wound J. 2019;16(1):96-102.

3. Hollenbeck ST, Toranto JD, Taylor BJ, Ho TQ, Zenn MR, Erdmann D, et al. Perineal and lower extremity reconstruction. Plast Reconstr Surg. 2011;128(5):551e-63e.

4. Salgarello M, Farallo E, Barone-Adesi L, Cervelli D, Scambia G, Salerno G, et al. Flap algorithm in vulvar reconstruction after radical, extensive vulvectomy. Ann Plast Surg. 2005;54(2):184-90.

5. Mughal M, Baker RJ, Muneer A, Mosahebi A. Reconstruction of perineal defects. Ann R Coll Surg Engl. 2013;95(8):539-44.

6. John HE, Jessop ZM, Di Candia M, Simcock J, Durrani AJ, Malata CM. An algorithmic approach to perineal reconstruction after cancer resection--experience from two international centers. Ann Plast Surg 2013;71(1):96-102.

7. Gentileschi S, Servillo M, Garganese G, Fragomeni S, De Bonis F, Scambia G, et al. Surgical therapy of vulvar cancer: how to choose the correct reconstruction? J Gynecol Oncol. 2016;27(6):e60.

8. Chokshi RJ, Kuhrt MP, Arrese D, Martin EW Jr. Reconstruction of total pelvic exenteration defects with rectus abdominus myocutaneous flaps versus primary closure. Am J Surg. 2013;205(1):64-70.

9. Saleh DB, Liddington MI, Loughenbury P, Fenn CW, Baker R, Burke D. Reconstruction of the irradiated perineum following extended abdomino-perineal excision for cancer: an algorithmic approach. J Plast Reconstr Aesthet Surg. 2012;65(11):1537-43.

10. Martin AL, Stewart JR, Girithara-Gopalan H, Gaskins JT, McConnell NJ, Medlin EE. Trends and complications of vulvar reconstruction after vulvectomy: a study of a nationwide cohort. Int $\mathbf{J}$ Gynecol Cancer. 2018;28(8):1606-15.

11. Dias-Jr AR, Soares-Jr JM, de Faria MBS, Genta MLND, Carvalho JP, Baracat EC. Secondary healing strategy for difficult wound closure in invasive vulvar cancer: a pilot case-control study. Clinics (Sao Paulo). 2019;74:e1218.

12. Huang JJ, Chang NJ, Chou HH, Wu CW, Abdelrahman M, Chen HY, et al. Pedicle perforator flaps for vulvar reconstruction--new generation of less invasive vulvar reconstruction with favorable results. Gynecol Oncol. 2015;137(1):66-72.

13. Chen YC, Scaglioni MF, Kuo YR. Profunda artery perforator based V-Y rotation advancement flap for total vulvectomy defect reconstruction--A case report and literature review. Microsurgery. 2015;35(8):66871.

14. Ito R, Huang JJ, Wu JC, Lin MC, Cheng MH. The versatility of profunda femoral artery perforator flap for oncological reconstruction after cancer resectionclinical cases and review of literature. J Surg Oncol. 2016;114(2):193-201.

15. Peiretti M, Corvetto E, Candotti G, Angioni S, Figus A, Mais V. New Keystone flap application in vulvoperineal reconstructive surgery: A case series. Gynecol Oncol Rep. 2019;30:100505.

16. Ramesh HS, Boase T, Audisio RA. Risk assessment for cancer surgery in elderly patients. Clin Interv Aging. 2006;1(3):221-7. 
17. De Hullu JA, Hollema H, Lolkema S, Boezen M, Boonstra H, Burger MP, et al. Vulvar carcinoma. The price of less radical surgery. Cancer. 2002;95(11):2331-8.

18. Llueca A, Herraiz JL, Del Moral R, Piquer D, Maazouzi Y, Segarra B, et al. Use of negative pressure wound therapy after infection and flap dehiscence in radical vulvectomy: A case report. Int J Surg Case Rep. 2017;41:370-2.

19. Imas GE, Sola MPB, Gomez MTG, Etulain CL. Prevalence study on vulvar neoplasia in Navarre from 2007 to 2015. Nurse Care Open Acces J. 2017;3(3):255-8. 